\title{
Phenolic compounds, antioxidant properties and antifungal activity of jarilla (Barkleyanthus salicifolius [Kunth] H. Rob \& Brettell)
}

\author{
Ahuitzolt de Jesús Joaquín-Ramos ${ }^{1}$, César Uriel López-Palestina², José Manuel Pinedo-Espinoza ${ }^{3}$, \\ Susana Elizabeth Altamirano-Romo ${ }^{1}$, Yair Olovaldo Santiago-Saenz ${ }^{2}$, César Leobardo Aguirre-Mancilla ${ }^{1}$, \\ and Jorge Gutiérrez-Tlahque ${ }^{4 *}$
}

\begin{abstract}
${ }^{1}$ Instituto Tecnológico de Roque, Departamento de Ingenierías, Carretera Celaya-Juventino Rosas km 8, Celaya Guanajuato C.P. 38110, México.

${ }^{2}$ Universidad Autónoma del Estado de Hidalgo, Instituto de Ciencias Agropecuarias, Av. Universidad Rancho Universitario km 1, Tulancingo Hidalgo C.P. 43600, México.

${ }^{3}$ Universidad Autónoma de Zacatecas, Carretera Zacatecas-Guadalajara km 15.5, Cieneguillas, C.P. 98000, Zacatecas, Zacatecas, México.

${ }^{4}$ Instituto Tecnológico de Zitácuaro, Av. Tecnológico Manzanillos No. 186, Zitácuaro Michoacán C.P. 61534 México.

*Corresponding author (jorge.gt@zitacuaro.tecnm.mx).
\end{abstract}

Received: 26 November 2019; Accepted: 31 March 2020; doi:10.4067/S0718-58392020000300352

\begin{abstract}
Plant biodiversity provides a natural source of several compounds with biological activity, such as antioxidant and antifungal properties; such effects are related with the concentrations of phenols and flavonoids and different organs of the plants. In this research, aqueous (W) and 70\% ethanol (Et70) extracts from flowers (F), leaves (L), stems (S) and roots (R) of Barkleyanthus salicifolius (Kunth) H. Rob. \& Brettell were used to test antioxidant and antifungal activities and also the total concentration of phenols and flavonoids were analyzed; and types of phenolic acids and flavonoids were determined for each plant organ extract by HPLC. The Et70 enhance the extraction process of phenols and flavonoids, also showed higher antifungal and antioxidant activities. The obtained extract of the Et70 $\times \mathrm{F}$ interaction showed the higher concentration of total phenols (57.90 mg GAE), flavonoids (91.03 mg QE) and antioxidant activity (285.07 Mm Trolox) per gram of dry extract. In addition, this extract shows an antifungal inhibition interval of $66.17 \%$ (Fusarium oxysporum) to $92.89 \%$ (Colletotrichum gloeosporioides). The phenol ferulic acid ( $\left.35.57 \mathrm{mg} \mathrm{g}^{-1}\right)$ and the flavonoid naringenina (206.60 $\mathrm{mg} \mathrm{g}^{-1}$ ) were the compounds with the highest values founded in Et70-R, both of them compounds had been tested against fungal pathogens. Data indicate that antifungal and antioxidant activities are in function of phenolic acids and flavonoids concentration, as well as solvent used to extraction. Therefore, $B$. salicifolius species growing on wild form have the ability of accumulate several compounds with biological activity.
\end{abstract}

Key words: Barkleyanthus salicifolius, flavonoids, HPLC, phenolic acids, phytopathogens, willow ragwort.

\section{INTRODUCTION}

Phytochemical compounds from medicinal plants have a wide range of biological activity, that include the antibiotic, antioxidant and anti-inflammatory activities (Canadanovic-Brunet et al., 2009). Polyphenols, phenolic acids and flavonoids are powerful antioxidants and its antibiotic, antiviral, anticarcinogen, anti-inflammatory and vasodilator effects have been described (Ghasemzadeh et al., 2011). On the other hand, phenolic compounds are usually related to defense responses in plants; through different mechanisms, as preformed inhibitors or as response-synthetized compounds against pathogen 
attack (Pusztahelyi et al., 2015). Also due to higher efficiency and low toxicity for humans, phenolic acids and flavonoids have been proposed as potential natural fungicides in order to control fungal phytopathogens, which are a threat for agriculture because damage to crops during developmental and postharvest phases causing high losses of fruits and vegetables (Zabka and Pavela, 2013).

Nowadays, phytopathogenic fungi are controlled by synthetic fungicides; however, their use is more restricted due to the negative impact over environment and human health; in addition, the fast development of fungal resistance to synthetic fungicides makes necessary to seek novelty and safe sources of molecules with antifungal and antioxidant activity: wild plants have a great potential because they accumulate thousands of secondary metabolites (Wianowska et al., 2016).

Over the last years, flavonoids have been used against fungal pathogen of plants, since some of them have the ability to inhibit the germination of fungal spores, meanwhile other cause deformation and cellular lysis (Pusztahelyi et al., 2015). Flavonoids such as quercetin and phenolic acids such as ferulic acid have shown antifungal activity against some phytopathogens as Alternaria alternata, Rhizoctonia solani, Fusarium oxysporum, Botrytis cinereae and Phytophthora infestans (Wianowska et al., 2016).

Barkleyanthus salicifolius (Kunth) H. Rob \& Brettell (ex Senecio salignus) belonging to Asteraceae family, commonly named jara, jaktin, jara-tokstini, buralillo, jarilla, barilla or willow ragwort, is a common bush of $1.5 \mathrm{~m}$ high, it grows alone or associated to genera of Poaceae spp., between pines forest and hillsides at an altitude between 1200 and $3000 \mathrm{~m}$ throughout the north, west and center of Mexico. Domínguez et al. (2005) reported that the antioxidant activity is higher in methanolic extracts of flowers than leaves. Barkleyanthus salicifolius is used as anti-inflammatory, antirheumatic, antimigraine, nephroprotective and hepatoprotective, properties that could be related with presence of terpenoids, alkaloids and flavonoids (Pérez-Ochoa et al., 2016).

Phenolic compounds content and antioxidant activity of extracts of $B$. salicifolius have been reported and the plant is used in folk medicine to control gastrointestinal disorders; however; there are few data about the kind and quantity of phenolic and flavonoids compounds present at organ level in B. salicifolius; data could open the door to study the secondary metabolites of $B$. salicifolius to control different diseases caused by fungi at crops. Therefore, the aim of this work was to determine and identify phenolic and flavonoids compounds and their antioxidant activity in ethanolic (70\%) and aqueous extracts from different organs of $B$. salicifolius and evaluate the effects against fungal phytopathogens.

\section{MATERIALS AND METHODS}

\section{Collected plant material}

Roots, stems, leaves and flowers of Barkleyanthus salicifolius (Kunth) H. Rob \& Brettell were collected during dry season on January 2018, at Zitacuaro (19 $25^{\prime} 44^{\prime \prime}$ N, $100^{\circ} 22^{\prime} 23^{\prime \prime}$ W; $1942 \mathrm{~m}$ a.s.1.), Michoacan, Mexico, where the accumulated precipitation was $917 \mathrm{~mm}^{3}$ and the annual average temperature was $17.6^{\circ} \mathrm{C}$. The weather of area is classified as Cwb according to Köppen (García, 2004). The plant was identified at the herbarium of the Universidad Autónoma del Estado de Hidalgo (collector: Hernández-Fuentes, A.D.; identification number 06).

\section{Preparation of the extracts}

A sample of $100 \mathrm{~g}$ dried roots (R), stems (S), leaves (L) or flowers (F) were mixed inside a $2 \mathrm{~L}$-glass bottle with $1000 \mathrm{~mL}$ solvent, deionized water (W) or 70\% ethanol solution (Et70). Mixtures were store in the dark at $20^{\circ} \mathrm{C}$ for $15 \mathrm{~d}$. Ethanolic extracts were vacuum evaporated in a rotary steamer at $45^{\circ} \mathrm{C}(\mathrm{V}-700$, Büchi, Flawil, Switzerland) to concentrate samples. Later, samples were frozen and freeze drying at $-40^{\circ} \mathrm{C}$ and $5 \mathrm{mPa}$ (Freezone 12, Labconco, Kansas City, Missouri, USA) to remove completely the solvent. Aqueous extract was directly frozen and freeze drying under previously described conditions. Samples were store in the dark at $4{ }^{\circ} \mathrm{C}$.

\section{Determination of total phenols content}

Total phenols content (TPC) was determined using the Folin-Ciocalteu method, described by Waterman and Mole (1994). Briefly, $1 \mathrm{~g}$ dried sample of roots, stems, leaves or flowers was mixed with $10 \mathrm{~mL} 70 \%$ ethanol and later shaken in a vortex (IKA, Staufen, Germany) during $30 \mathrm{~min}$ and later was centrifuged at $10000 \times \mathrm{g}$ (ST 16R, Thermo Fisher Scientific, 
Waltham, Massachusetts, USA) for $10 \mathrm{~min}$ at $5{ }^{\circ} \mathrm{C}$ and the supernatant was recovered. After, $5 \mathrm{~mL}$ Folin-Ciocalteu reactant diluted 1:10 with distilled and deionized water were added to supernatant and left to rest for $7 \mathrm{~min}$; later $4 \mathrm{~mL}$ sodium carbonate anhydrous $(7.5 \% \mathrm{w} / \mathrm{v})$ was added, the reaction was carried on for $2 \mathrm{~h}$. Finally, the absorbance was measured at $760 \mathrm{~nm}$ in a UV/Vis spectrophotometer (6715, Jenway, Cole-Parmer, Staffordshire, UK). The results were expressed as milligrams of gallic acid equivalents per gram of dried extract (mg GAE g$\left.{ }^{-1} \mathrm{DE}\right)$.

\section{Determination of total flavonoid content}

Total flavonoid content (TFC) was determined according to the method described by Chang et al. (2002) where $2 \mathrm{~mL}$ supernatant were mixed with $2 \mathrm{~mL}$ distilled water and $0.15 \mathrm{~mL} \mathrm{NaNO}_{2}(5 \% \mathrm{w} / \mathrm{v})$; after $5 \mathrm{~min}, 0.15 \mathrm{~mL} \mathrm{AlCl} \mathrm{Al}_{3} \cdot 6 \mathrm{H}_{2} \mathrm{O}(10 \%$ $\mathrm{w} / \mathrm{v}$ ) solution was added and the mix was store at room temperature for another $5 \mathrm{~min}$; later, $1 \mathrm{~mL} \mathrm{NaOH}(1 \mathrm{M})$ solution was added. The mix was left for $15 \mathrm{~min}$ in darkness; finally, absorbance was measured at $415 \mathrm{~nm}$. The results were expressed as milligrams of quercetin equivalents per gram of dried extract ( $\left.\mathrm{mg} \mathrm{QE}^{-1} \mathrm{DE}\right)$.

\section{Antioxidant activity}

Antioxidant activity by 2,2'-diphenyl-1-picrylhydrazyl (DPPH) method was determined according to Brand-Williams et al. (1995). Sample $(500 \mu \mathrm{L})$ was taken from the supernatant obtained of extractions and was mixed with $2500 \mu \mathrm{L}$ $\mathrm{DPPH}^{\cdot}$ solution $6 \times 10^{-5} \mathrm{M}$ previously prepared. The mix was store for $1 \mathrm{~h}$ in darkness and at room temperature, later the absorbance was measured at $517 \mathrm{~nm}$. The results are reported as $\mu \mathrm{M}$ of Trolox per gram of dried extract $\left(\mu \mathrm{M} \mathrm{T} \mathrm{g}^{-1} \mathrm{DE}\right)$.

On the other hand, antioxidant activity by $2,2^{\prime}$-azino-bis(3-ethylbenzothiazoline-6-sulfonic acid) (ABTS) method was measured according to Re et al. (1999). The ABTS $^{++}$was prepared as follows: ABTS (7 mM) was mixed with $10 \mathrm{~mL}$ potassium persulfate $(2.45 \mathrm{mM})$ and shaken for $16 \mathrm{~h}$ protected from light. Later, when radical was obtained, a sample $(100 \mu \mathrm{L})$ of supernatant (phenols and flavonoid extractions) was mixed with $3 \mathrm{~mL} \mathrm{ABTS}{ }^{\circ+}$ (stabilized reagent) and shook for $15 \mathrm{~s}$, later the samples were stored for $6 \mathrm{~min}$ in darkness. After, absorbance was measured at $734 \mathrm{~nm}$. The results were expressed as $\mu \mathrm{M}$ of Trolox per gram of dried extract $\left(\mu \mathrm{M} \mathrm{T} \mathrm{g} \mathrm{g}^{-1} \mathrm{DE}\right)$.

\section{Antifungal activity}

Phytopathogenic microorganisms used to assay the antifungal activity of the extracts were: the fungi Sclerotium rolfsii, Colletotrichum gloeosporioides (provided by laboratory of Phytopathology of Colegio de Posgraduados campus Montecillos, Estado de Mexico, Mexico), Fusarium oxysporum and Rhizoctonia solani and the oomycete Phytophthora capsici (provided by Instituto Nacional de Investigaciones Forestales, Agrícolas y Pecuarias [INIFAP], experimental field of the Bajío, Guanajuato, Mexico).

The strains were preserved on potato dextrose agar (PDA) (BD Bioxon, Becton Dickinson, Mexico) and stored at $4{ }^{\circ} \mathrm{C}$. A $5 \mathrm{~mm}$ diameter disc of each phytopathogen was inoculated on PDA plates $(90 \times 15 \mathrm{~mm})$ and incubated at $28{ }^{\circ} \mathrm{C}$ for 8 $\mathrm{d}$ at microbiological incubator (FE-133D, Felisa, Mexico).

Quantitative determination was carried out according to Meléndez-González et al. (2015). The media for antifungal activity assays were prepared by sterilizing a $2 \mathrm{X}$ of PDA solution that was diluted to $1 \mathrm{X}$ with sterile water; previously each extract was dissolved on sterile water and added to final solution obtaining $250 \mu \mathrm{g} \mathrm{mL}^{-1}$ each extract in the media. Temperature was maintained at $40-45^{\circ} \mathrm{C}$ during the process to keep a liquid medium and minimize the effects of high temperatures on the active compounds of the extracts; the prepared media were 10 for each phytopathogen: 8 for aqueous and ethanolic extracts of roots, stems, leaves and flowers; 1 negative control (medium without extract) and 1 positive control (250 $\mu \mathrm{g} \mathrm{mL}^{-1}$ captan; 2-(trichloromethylsulfanyl)-3a,4,7,7a-tetrahydroisoindole-1,3-dione). Four replicates of each treatment were used during the assay. Radial growth was recorded after $7 \mathrm{~d}$ of incubation. Percentage inhibition was calculated according to the following equation:

$$
\% \text { inh }=\left[\left(A_{C}-A_{P}\right) / A_{C}\right] \times 100
$$

where \%inh is percentage of radial growth inhibition, $A_{C}$ is fungal or oomycete growth on negative control, and $A_{P}$ is fungal or oomycete growth on medium with extract or captan.

\section{Identification of phenolic compounds}

Phenolic acids and flavonoids were determined according to Aguiñiga-Sánchez et al. (2017). Analytes of the extracts were identified by high performance liquid chromatography (HPLC Agilent 1100, Agilent Technologies, Santa Clara, California, 
USA). Phenolic acids were determined using a Nucleosil 100 SA column (Macherey-Nagel, Düren, Germany): $125 \times 4.0$ $\mathrm{mm}$ id and particle size $5 \mu \mathrm{m}$; with gradient elution, using $\mathrm{H}_{2} \mathrm{O}$ at pH 2.5 with trifluoroacetic acid (TFA) as solution A and acetonitrile (ACN) as solution B, as follows: $10 \mathrm{~min}, 85 \% \mathrm{~A} ; 20 \mathrm{~min}, 65 \% \mathrm{~A} ; 23 \mathrm{~min}, 65 \% \mathrm{~A}$. The injection volume was $20 \mu \mathrm{L}$, with a flow of $1 \mathrm{~mL} \mathrm{~min}^{-1}$ at $22{ }^{\circ} \mathrm{C}$; detection was carried out at $280 \mathrm{~nm}$ at an analysis time of $25 \mathrm{~min}$. Standards used were caffeic, gallic, chlorogenic, vanillic, $p$-hydroxybenzoic, $p$-coumaric, ferulic and syringic acids (Sigma-Aldrich, St. Louis, Missouri, USA) and were injected at the same conditions. Regarding to flavonoids, the analysis was carried out using a column Hypersil ODS (Agilent): $125 \times 40 \mathrm{~mm}$ id, particle size $5 \mu \mathrm{m}$, with gradient elution, using as solution A and $\mathrm{B}$ under the same conditions used for the phenolic acids; only with different gradients (10 min, 65\% A; 20 min, 65\% A; $25 \mathrm{~min}, 65 \% \mathrm{~A})$ and temperature flow $\left(25^{\circ} \mathrm{C}\right)$. Detection was carried out at an analysis time of $25 \mathrm{~min}$. Standards used were rutin, phloridzin, myricetin, quercetin, naringenin, phloretin and galangin (Sigma Aldrich) and were injected at the same conditions. Results are expressed as $\mu \mathrm{g}$ per gram of dried extract $\left(\mu \mathrm{g} \mathrm{g}{ }^{-1} \mathrm{DE}\right)$.

\section{Experimental design and statistical analysis}

Data were analyzed using a two-factorial ANOVA ( $\mathrm{P} \leq 0.05)$ as follows: the solvent with two levels (water and $70 \%$ ethanol) and plant organs with four levels (root, stems, leaves and flowers). The ANOVA was followed by comparison of means by Tukey method with $\mathrm{P} \leq 0.05$ for each one of response variables analyzed.

\section{RESULTS AND DISCUSSION}

\section{Solvents, phenolic compounds and antioxidant activity}

Table 1 shows the antioxidant activity by inhibition of $\mathrm{ABTS}^{*+}$ and $\mathrm{DPPH}^{\cdot}$ radicals; the higher activity was for Et70 extracts of jarilla, also higher phenolic compounds were showed; similar results were reported in other research (Ahmed et al., 2011); some authors reported that a binary system solvent has a better performance than a mono-solvent, water or pure ethanol (Do et al., 2014). Also, both types of solvents used for the extraction of antioxidant compounds recorded a higher antioxidant activity in the ABTS*+ assay compared to DPPH.

Table 1. Antioxidant activity and total phenols and flavonoids content of leaves, stems, roots and flowers of Barkleyanthus salicifolius.

\begin{tabular}{|c|c|c|c|c|}
\hline Treatment & $\begin{array}{c}\text { ABTS }^{*+} \text { radical } \\
\text { scavenging activity }\end{array}$ & $\begin{array}{c}\mathrm{DPPH}^{\cdot+} \text { radical } \\
\text { scavenging activity }\end{array}$ & $\begin{array}{l}\text { Total phenols } \\
\text { content }\end{array}$ & $\begin{array}{c}\text { Total flavonoids } \\
\text { content }\end{array}$ \\
\hline & $\longrightarrow \mu \mathrm{M}$ & $\mathrm{ox} \mathrm{g}^{-1} \mathrm{DE} \longrightarrow$ & mg GAE $g^{-1} \mathrm{DE}$ & $\mathrm{mg} \mathrm{QE} \mathrm{g} \mathrm{g}^{-1} \mathrm{DE}$ \\
\hline \multicolumn{5}{|c|}{ Extraction solvent effect } \\
\hline Et70 & $192.43 \mathrm{a}$ & $75.35 \mathrm{a}$ & $31.92 \mathrm{a}$ & $31.99 \mathrm{a}$ \\
\hline Water (W) & $56.29 b$ & $25.50 \mathrm{~b}$ & $3.67 \mathrm{~b}$ & $2.25 b$ \\
\hline \multicolumn{5}{|c|}{ Plant organ effect } \\
\hline Flower $(\mathrm{F})$ & $208.97 \mathrm{a}$ & $69.94 \mathrm{a}$ & $31.98 \mathrm{a}$ & $48.21 \mathrm{a}$ \\
\hline Leaf $(\mathrm{L})$ & $108.73 b$ & $43.61 b$ & $11.39 \mathrm{c}$ & $6.82 \mathrm{c}$ \\
\hline Root (R) & $92.57 \mathrm{c}$ & $42.30 \mathrm{c}$ & $17.22 \mathrm{~b}$ & $9.15 b$ \\
\hline Stem $(S)$ & $87.13 d$ & $39.87 \mathrm{~d}$ & $10.60 d$ & $4.31 \mathrm{~d}$ \\
\hline \multicolumn{5}{|c|}{ Extraction solvent $\times$ Plant organ interaction effect } \\
\hline $\mathrm{Et} 70 \times \mathrm{F}$ & $285.07 \mathrm{a}$ & $83.58 \mathrm{a}$ & $57.90 \mathrm{a}$ & $91.03 \mathrm{a}$ \\
\hline Et70 $\times L$ & $169.33 b$ & $75.38 b$ & $19.20 \mathrm{c}$ & $10.51 \mathrm{c}$ \\
\hline Et70 $\times$ R & $161.77 \mathrm{c}$ & $72.70 \mathrm{c}$ & $32.28 b$ & $18.05 b$ \\
\hline $\mathrm{Et} 70 \times \mathrm{S}$ & $153.53 \mathrm{~d}$ & $69.77 d$ & $18.31 d$ & $8.35 d$ \\
\hline $\mathrm{W} \times \mathrm{F}$ & $132.88 \mathrm{e}$ & $56.30 \mathrm{e}$ & $6.06 \mathrm{e}$ & $5.39 \mathrm{e}$ \\
\hline $\mathrm{W} \times \mathrm{L}$ & 48.14f & $23.84 \mathrm{f}$ & $4.49 \mathrm{f}$ & $3.12 \mathrm{f}$ \\
\hline $\mathrm{W} \times \mathrm{R}$ & $23.37 \mathrm{~g}$ & $11.90 \mathrm{~g}$ & $2.17 \mathrm{~g}$ & $0.26 \mathrm{~g}$ \\
\hline $\mathrm{W} \times \mathrm{S}$ & $20.74 \mathrm{~h}$ & $9.97 \mathrm{~h}$ & $1.99 \mathrm{~g}$ & $0.25 \mathrm{~g}$ \\
\hline
\end{tabular}

Values are mean of three replicates. Same letters in each column are significantly equal (Tukey, $\mathrm{p} \leq 0.05$ ).

ABTS: 2,2'-Azinobis-(3-ethylbenzothiazoline-6-sulfonic acid); DPPH: 2,2'-diphenyl-1-picrylhydrazyl; Et70: 70\% ethanol; QE: quercetin equivalents; GAE: gallic acid equivalents; DE: dried extract. 
The antioxidant activity by $\mathrm{ABTS}^{\circ+}$ and $\mathrm{DPPH}^{*}$ as well as total content of phenols and flavonoids were significantly different for each plant organ (Table 1); flowers showed the highest antioxidant activity and total content of phenols and flavonoids, meanwhile the lowest values were for stems. There are reports of cell damage caused to reproductive tissues by different types of abiotic stress, this damage has effects in the number and quality of the seeds (De Storme and Geelen, 2014); and the increase of the reactive oxygen species (ROS) is associated to stress damage like light, cold and drought (Smith and Zhao, 2016).

On the other hand, leaves were the second organ with the highest antioxidant activity (Table 1). The photosynthesis process requires luminous energy and often this energy exceeds the amount manageable by the photosystems and the photodamage is triggered; however, plants have several mechanisms to protect the photosynthetic system, since the repair of the proteins involved, such as D1 (Kato and Sakamoto, 2009), until to the synthesis of compounds to dissipate excess energy and neutralize ROS generated during the photosynthesis process (Varela et al., 2016). Therefore, compounds such as phenols and flavonoids could be involved in the response protection of the photosynthetic apparatus of plants.

Roots showed a total content of phenols and flavonoids only lower than flowers but higher than leaves and stems (Table 1); similar data were found in another works (Bazdar et al., 2018). Roots are the first tissue that detects a condition of water deficit and induces signs of stress (Michel et al., 2012; Gutiérrez-Tlahque et al., 2019); the plant material was collected during cold-dry season, this environment could induce the accumulation of secondary metabolites, including phenolic compounds, which may play an important role in resistance to abiotic stress (Varela et al., 2016).

Interactions among the solvent extraction and plant organ of B. salicifolius are showed in Table 1. Organ hydroalcoholic extracts showed higher phenols and flavonoid content as well as higher antioxidant activity by $\mathrm{ABTS}^{*+}$ and $\mathrm{DPPH}^{*}$ assays than organ aqueous extracts. The highest antioxidant activity was found in the Et70 $\times \mathrm{F}$ interaction, meanwhile in the interaction $\mathrm{W} \times \mathrm{S}$ the lowest antioxidant activity values were recorded, these results follow a similar pattern as reported by Bazdar et al. (2018) at the plant Prangos ferulacea relative to the total content of phenols and flavonoids and the ability to inactivate the DPPH' radical; some studies had showed that increasing the percentages of water in solvents (alcohol, methanol, acetone) the concentrations of phenols and total flavonoids increase as well as the antioxidant activity (Anwar and Przybylski, 2012; Do et al., 2014), probably because the hydroalcoholic extracts contain polar and non-polar compounds.

The concentration of phenols and total flavonoids in Et70-R extracts is only below the concentration of the Et70 $\times \mathrm{F}$ interaction; meanwhile, in antioxidant activity the values are below the Et70 $\times \mathrm{L}$ interaction that have less phenols and flavonoids, that is, there is no relation between concentration of phenols and flavonoids and antioxidant activity. The synthesis of secondary metabolites in plant systems is conditioned to the environment where they are growing to help them to survive, in addition, the tissues between genera and plant species can interact differently with solvents used for the extraction of phenolic compounds and even affect the chemical structure of these compounds, resulting in variations in antioxidant activity (Bystrická et al., 2010).

\section{Effects of solvent and plant organ on antifungal activity}

Antifungal activity in relation to the solvent was assessed against phytopathogenic fungi Sclerotium rolfsii, Colletotrichum gloeosporioides, F. oxysporum, Rhizoctonia solani and the oomicete Phytophthora capsici (Table 2). The highest antifungal activity was developed by ethanolic extracts which could be related to the content of phenolic compounds which is the highest in ethanolic extracts. Differences in inhibition values of different treatments could be due to interactions of phenolic compounds with membrane proteins of different phytopathogens and to the mechanisms that microorganisms begin in response to the presence of phenols and flavonoids (Rodríguez-Pedroso et al., 2012; Pusztahelyi et al., 2015).

When factor organ of the plant was analyzed (Table 2), extracts of flower showed the highest antifungal activity followed by leaf, root and stem for fungi $F$. oxysporum, $S$. rolfsii and $R$. solani; the stem showed the lowest antifungal activity except for $P$. capsici and $C$. gloeosporioides where the lowest antifungal activity was of root extracts; however, nonsignificant difference in growth inhibition of $P$. capsici between leaf and stem extracts were observed; according to Rhouma et al. (2009) these secondary metabolites are preformed antibiotics and further synthesized from remote precursors in response to pathogen attack. 
Table 2. Antifungal activity from extracts of Barkleyanthus salicifolius expressed as mycelial growth inhibition percentage.

\begin{tabular}{|c|c|c|c|c|c|}
\hline Treatment & $\begin{array}{l}\text { Fusarium } \\
\text { oxysporum }\end{array}$ & $\begin{array}{l}\text { Phytophthora } \\
\text { capsici }\end{array}$ & $\begin{array}{l}\text { Colletotrichum } \\
\text { gloeosporioides }\end{array}$ & $\begin{array}{l}\text { Sclerotium } \\
\text { rolfsii }\end{array}$ & $\begin{array}{c}\text { Rhizoctonia } \\
\text { solani }\end{array}$ \\
\hline \multicolumn{6}{|c|}{ Extraction solvent effect } \\
\hline Et70 & $29.05 \mathrm{a}$ & $59.80 \mathrm{a}$ & $61.77 \mathrm{a}$ & $49.38 \mathrm{a}$ & $46.23 a$ \\
\hline Water (W) & $25.14 \mathrm{~b}$ & $47.68 b$ & $21.97 \mathrm{~b}$ & $22.28 b$ & $12.21 \mathrm{~b}$ \\
\hline \multicolumn{6}{|c|}{ Plant organ effect } \\
\hline Flower $(\mathrm{F})$ & $58.35 \mathrm{a}$ & $70.91 \mathrm{a}$ & $53.53 \mathrm{a}$ & $82.80 \mathrm{a}$ & $60.69 a$ \\
\hline Leaf (L) & $34.48 \mathrm{~b}$ & $47.40 \mathrm{~b}$ & $47.01 \mathrm{~b}$ & $42.45 b$ & $24.81 \mathrm{~b}$ \\
\hline Root (R) & $11.41 \mathrm{c}$ & $46.32 c$ & $30.24 d$ & $11.70 \mathrm{c}$ & $21.49 \mathrm{c}$ \\
\hline Stem (S) & $4.12 d$ & $50.33 b$ & $36.75 \mathrm{c}$ & $6.41 d$ & $9.88 \mathrm{~d}$ \\
\hline \multicolumn{6}{|c|}{ Extraction solvent $\times$ Plant organ interaction effect } \\
\hline Et70 $\times \mathrm{F}$ & $66.17 \mathrm{a}$ & $82.53 \mathrm{a}$ & $92.89 \mathrm{a}$ & $89.46 \mathrm{a}$ & $83.64 \mathrm{a}$ \\
\hline $\mathrm{Et} 70 \times \mathrm{L}$ & $59.69 b$ & $48.86 \mathrm{~cd}$ & $68.41 b$ & $82.03 b$ & $44.85 b$ \\
\hline Et70 $\times R$ & $18.30 \mathrm{~d}$ & $50.09 \mathrm{c}$ & $38.97 \mathrm{~d}$ & $13.47 \mathrm{~d}$ & $37.16 \mathrm{c}$ \\
\hline Et70 $\times S$ & 6.79ef & $57.73 b$ & $46.81 \mathrm{c}$ & $12.59 \mathrm{~d}$ & $19.28 \mathrm{~d}$ \\
\hline $\mathrm{W} \times \mathrm{F}$ & $50.53 c$ & $59.30 \mathrm{~b}$ & $38.68 \mathrm{~d}$ & $60.13 \mathrm{c}$ & $37.74 \mathrm{c}$ \\
\hline $\mathrm{W} \times \mathrm{L}$ & $9.28 \mathrm{e}$ & 45.94de & $0.97 f$ & $2.86 \mathrm{e}$ & $4.78 \mathrm{e}$ \\
\hline $\mathrm{W} \times \mathrm{R}$ & $4.52 \mathrm{ef}$ & $42.93 \mathrm{ef}$ & $21.50 \mathrm{e}$ & $9.89 \mathrm{~d}$ & $5.82 \mathrm{e}$ \\
\hline $\mathrm{W} \times \mathrm{S}$ & $1.47 f$ & $42.53 f$ & $26.71 \mathrm{e}$ & $0.22 \mathrm{e}$ & $0.50 \mathrm{f}$ \\
\hline
\end{tabular}

Means with same letters in each column are significantly equal according to Tukey $(\mathrm{p} \leq 0.05)$.

Et70: $70 \%$ Ethanol.

The analysis of the interaction Solvent $\times$ Plant organ on the inhibition of phytopathogenic fungi (Table 2) showed that the highest percentage of inhibition on F.oxysporum, C. gloeosporioides, P. capsici, S. rolfsii and R. solani was for Et70 $\times \mathrm{F}$ interaction, which also showed the highest antioxidant activity and content of phenolic compounds (Table 3), characteristics that have been positively related to antifungal activity similar to the reported by Jeyaseelan et al. (2012) in the plant Lawsonia inermis. The interactions $\mathrm{W} \times \mathrm{S}$ and $\mathrm{W} \times \mathrm{R}$ had the lowest inhibition percentage for fungi $F$. oxysporum, $P$. capsici and $C$. gloeosporioides; meanwhile the $\mathrm{W} \times \mathrm{S}$ interaction showed the lowest antifungal activity against $S$. rolfsii and $R$. solani; the solvent used to extract secondary metabolites with antifungal properties is an important factor; for example, Eloff et al. (2017) used solvents with different polarities at the plant Melianthus comosus found that the best averages of minimum inhibitory concentrations for different fungi were into the range of 3.1 to 5.1 (polarities), where the ethanol is located.

Table 3. Phenolic acids and flavonoids content in the extracts of different organs of Barkleyanthus salicifolius.

\begin{tabular}{|c|c|c|c|c|c|c|c|c|}
\hline & $\mathrm{Et} 70 \times \mathrm{F}$ & $\mathrm{W} \times \mathrm{F}$ & $\mathrm{Et} 70 \times \mathrm{L}$ & $\mathrm{W} \times \mathrm{L}$ & $\mathrm{Et} 70 \times \mathrm{R}$ & $\mathrm{W} \times \mathrm{R}$ & $\mathrm{Et} 70 \times \mathrm{S}$ & $\mathrm{W} \times \mathrm{S}$ \\
\hline & & & & $\mu \mathrm{g} \mathrm{g}^{-1}$ & d extract & & & \\
\hline \multicolumn{9}{|l|}{ Phenolic acids } \\
\hline Gallic & 41.07 & 9.43 & 29.91 & 12.90 & 184.08 & 11.87 & 64.46 & 50.65 \\
\hline Chlorogenic & 252.22 & 1285.61 & 6890.16 & 161.24 & 8468.95 & 271.33 & 2567.92 & 176.33 \\
\hline Syringic & 38.28 & 85.12 & 571.78 & ND & 631.95 & 56.08 & 35.68 & 218.18 \\
\hline Vanillic & 29.11 & 112.83 & 1349.98 & 109.06 & 203.43 & 26.93 & 469.96 & 25.47 \\
\hline$p$-Hydroxy-benzoic & 797.51 & ND & ND & 52.68 & ND & 95.03 & 110.22 & ND \\
\hline Caffeic & 38.73 & 84.08 & 1725.68 & 3273.00 & 43.20 & ND & 312.97 & 153.75 \\
\hline Ferulic & 85.18 & 236.38 & 3921.50 & 75.20 & 35575.45 & 148.43 & 39.33 & 30.84 \\
\hline$p$-Coumaric & 919.16 & 10.48 & 20.39 & 15.08 & 11092.05 & 28.68 & 67.63 & 11.83 \\
\hline \multicolumn{9}{|l|}{ Flavonoids } \\
\hline Rutin & 1076.82 & 1699.67 & 1672.69 & 310.59 & 827.11 & 369.41 & 267.75 & 155.88 \\
\hline Phloridzin & 5203.71 & 15683.48 & 13156.42 & 3558.60 & 1562.20 & 7715.31 & 181.84 & 1661.24 \\
\hline Myricetin & 85.51 & 825.59 & 4079.86 & 1111.81 & ND & 4172.46 & ND & 625.72 \\
\hline Quercetin & 184.64 & 14.56 & 323.12 & 471.84 & 6773.83 & 1683.58 & 386.65 & 102.21 \\
\hline Naringenin & 12482.31 & 279.71 & 79802.34 & 10656.87 & 206593.55 & 12480.03 & 5323.10 & 15246.81 \\
\hline Phloretin & 3464.51 & 26.12 & 140.27 & 5137.70 & 2597.81 & 583.50 & 101.90 & 780.81 \\
\hline Galangin & 2765.02 & 121.67 & 5345.72 & 1311.47 & 17710.56 & 157.50 & 304.82 & 309.09 \\
\hline
\end{tabular}

Data are mean of two replicates.

ND: Not detected; Et70: 70\% ethanol; W: water; F: flower; L: leaf; R: root; S: stem. 


\section{Identification of phenolic compounds and flavonoids by HPLC}

Table 3 shows the concentrations of phenolic compounds identified by HPLC among different treatments; some phenolic compounds analyzed have not been reported in B. salicifolius extracts. The highest concentrations of chlorogenic acid, belonging to the hydroxycinnamic acids group, were found in W-F, Et70-L, W-L, W-R and Et70-S extracts; while p-coumaric acid was most commonly presented in Et70-F and Et70-R extracts. The syringic acid was detected at high amounts in the Et70-R, Et70-L and W-T in reference to other extracts; meanwhile the p-hydroxybenzoic acid was determined at 7-fold concentration in Et70-F comparing to Et70-S extract, which is followed by the aqueous extracts of root and leaf.

Some natural phenolic acids have been shown antifungal activity and have been considered as biofungicides; chlorogenic acid is related to the inhibition of fungal pathogens relevant for horticultural crops (Martínez et al., 2017); also, antifungal activity of $p$-coumaric acid, caffeic acid, vanillic acid, gallic acid, ferulic acid and syringic acid have been showed against $F$. oxysporum, Fusarium verticillioides, Penicillium brevicompactum, P. expansum, Aspergillus flavus and A. fumigatus (Zabka and Pavela, 2013). Caffeic and gallic acids individually did not show effect on Candida tropicalis but had a synergistic effect in association with fluconazole (Lima et al., 2016). The activity could be a dynamic response in the accumulation of phenolic compounds by plants to stressful situations.

Flavonoids concentration of B. salicifolius for each plant organ, are shown in Table 3. A novelty research has been made because there are no previous reports in the literature regarding to these types of extracts. All compounds were detected in all eight extracts except myricetin, that was not detected in Et70-R and Et70-S. Flavone naringenin was the compound detected in highest amounts in Et70-R, then quercetin followed by phloretin in W-L, galangin in Et70-R, and phloridzin in Et70-F, among the highest concentrations detected. Flavonols as quercetin, myricetin, rutin, naringenin and galangin isolated from various sources showed inhibitory effect against Candida albicans at minimum inhibitory concentrations (MIC) within the range of 4 to $441 \mu \mathrm{g} \mathrm{mL}^{-1}$ (Seleem et al., 2017); on the other hand, quercetin and rutin showed a synergistic effect in combination with amphotericin B against Cryptococcus neoformans (Oliveira et al., 2016).

The use of flavonoids extracted from wild plants with medicinal uses for the control of bacterial and fungal diseases has become very important, as they can be precursors of toxic substances for some pathogens (Rhouma et al., 2009). The mechanism by which flavonoids can inhibit microorganisms are the vital enzymatic pathways, such as cytochrome P450-dependent oxidases, in which flavonoids specifically block steroid hydroxylase enzymes (Arif et al., 2009); thus, the presence of these compounds and their characteristics allow to consider B. salicifolius extracts as an alternative for the biocontrol of plant pathogenic microorganisms.

\section{CONCLUSIONS}

The use of $70 \%$ ethanol allowed to extract higher concentration of phenolic acids and flavonoids than water from the Barkleyanthus salicifolius and favored antioxidant activity; the antifungal activity of the different extracts against five phytopathogens, showed differences between extracts of the organs and depending on the solvent used. The metabolites identified by HPLC had not been described previously in B. salicifolius extracts, but their antifungal activity has been tested individually and synergistically, either with other molecules of natural origin or with compounds used commercially to eradicate fungal infections of plants. These results show that wild plants used in traditional medicine remain an option as source of compounds with biological activity for the biocontrol of crop diseases and in other fields of human interest such as the pharmaceutical industry.

\section{ACKNOWLEDGEMENT}

This work was supported by Tecnológico Nacional de México/Instituto Tecnológico de Zitácuaro (6633.18-P); PRODEP (ITZIT-CA-29103). 


\section{REFERENCES}

Aguiñiga-Sánchez, I., Cadena-Íñiguez, J., Santiago-Osorio, E., Gómez-García, G., Mendoza-Núñez, V.M., Ruíz-Ramos, M., et al. 2017. Chemical analyses and in vitro and in vivo toxicity of fruit methanol extract of Sechium edule var. nigrum spinosum. Pharmaceutical Biology 55(1):1638-1645. doi:10.1080/13880209.2017.1316746.

Ahmed, J., Güvenc, A., Baldemir, A., Coskun, M., and Kucukboyaci, N. 2011. Total phenolic contents and antioxidant activities of Prangos Lindl. (Umbelliferae) species growing in Konya province (Turkey). Turkish Journal of Biology 35(3):353-360. doi:10.3906/biy-0809-23.

Anwar, F., and Przybylski, R. 2012. Effect of solvents extraction on total phenolics and antioxidant activity of extracts from flaxseed (Linum usitatissimum L.) Acta Scientiarum Polonorum Technologia Alimentaria 11(3):293-302.

Arif, T., Bhosale, J.D., Kumar, N., Mandal, T.K., Bendre, R.S., Lavekar, G.S., et al. 2009. Natural products - antifungal agents derived from plants. Journal of Asian Natural Products Research 11(7):621-638. doi:10.1080/10286020902942350.

Bazdar, M., Sadeghi, H., and Hosseini, S. 2018. Evaluation of oil profiles, total phenols and phenolic compounds in Prangos ferulacea leaves and flowers and their effects on antioxidant activities. Biocatalysis and Agricultural Biotechnology 14:418423. doi:10.1016/j.bcab.2018.04.009.

Brand-Williams, W., Cuvelier, M.E., and Berset, C. 1995. Use of a free radical method to evaluate antioxidant activity. LWTFood Science and Technology 28(1):25-30. doi:10.1016/S0023-6438(95)80008-5.

Bystrická, J., Vollmannová, A., Margitanová, E., and Cicová, I. 2010. Dynamics of polyphenolics formation in different plant parts and different growth phases of selected buckwheat cultivars. Acta Agriculturae Slovenica 95(3):225-230. doi:10.2478/v10014-010-0014-0.

Canadanovic-Brunet, J.M., Cetkovic, G.S., Djilas, S.M., Tumbas, V.T., Savatovic, S.S., Mandié, A.I., et al. 2009. Radical scavenging and antimicrobial activity of horsetail (Equisetum arvense L.) extracts. International Journal of Food Science \& Technology 44(2):269-278. doi:10.1111/j.1365-2621.2007.01680.x.

Chang,C.C., Yang,M.H.,Wen,H.M., and Chern,J.C.2002. Estimation of total flavonoid content in propolis by two complementary colorimetric methods. Journal of Food and Drug Analysis 10(3):178-182. doi:10.1097/00024382-199907000-00009.

De Storme, N., and Geelen, D. 2014. The impact of environmental stress on male reproductive development in plants: Biological processes and molecular mechanisms. Plant, Cell \& Environment 37(1):1-18. doi:10.1111/pce.12142.

Do, Q.D., Angkawijaya, A.E., Tran-Nguyen, P.L., Huynh, L.H., Soetaredjo, F.E., Ismadji, S., et al. 2014. Effect of extraction solvent on total phenol content, total flavonoid content, and antioxidant activity of Limnophila aromatica. Journal of Food and Drug Analysis 22(3):296-302. doi:10.1016/j.jfda.2013.11.001.

Domínguez, M., Nieto, A., Marin, J.C., Keck, A.-S., Jeffery, E., and Céspedes, C.L. 2005. Antioxidant activities of extracts from Barkleyanthus salicifolius (Asteraceae) and Penstemon gentianoides (Scrophulariaceae). Journal of Agricultural and Food Chemistry 53(15):5889-5895. doi:10.1021/jf0504972.

Eloff, J.N., Angeh, I.E., and McGaw, L.J.2017. Solvent-solvent fractionation can increase the antifungal activity of a Melianthus comosus (Melianthaceae) acetone leaf extract to yield a potentially useful commercial antifungal product. Industrial Crops and Products 110:103-112. doi:10.1016/j.indcrop.2017.11.014.

García, E. 2004. Modificaciones al sistema de clasificación climática de Köppen. In García, E. (ed.) $5^{\text {th }}$ ed. Universidad Nacional Autónoma de México, Ciudad de México.

Ghasemzadeh, A., Jaafar, H.Z.E., and Rahmat, A. 2011. Effects of solvent type on phenolics and flavonoids content and antioxidant activities in two varieties of young ginger (Zingiber officinale Roscoe) extracts. Journal of Medicinal Plants Research 5(7):1147-1154. http://www .academicjournals.org/JMPR.

Gutiérrez-Tlahque, J., Aguirre-Mancilla, C.L., López-Palestina, C., Sánchez-Fernández, R.E., Hernández-Fuentes, A.D., and Torres-Valencia, J.M. 2019. Constituents, antioxidant and antifungal properties of Jatropha dioica var. dioica. Natural Product Communications 14(5):1934578X19852433. doi:10.1177/1934578X19852433.

Jeyaseelan, E.C., Vinuja, T., Pathmanathan, K., and Jeyadevan, J.P. 2012. Control of plant pathogenic fungi using organic solvent extracts of leaf, flower and fruit of Lawsonia inermis L. International Journal of Pharmaceutical \& Biological Archives 3(4):783-788.

Kato, Y., and Sakamoto, W. 2009. Protein quality control in chloroplasts: A current model of D1 protein degradation in the photosystem II repair cycle. Journal of Biochemistry 146(4):463-469. doi:https://doi.org/10.1093/jb/mvp073.

Lima, V.N., Oliveira-Tintino, C.D.M., Santos, E.S., Morais, L.P., Tintino, S.R., Freitas, T.S., et al. 2016. Antimicrobial and enhancement of the antibiotic activity by phenolic compounds: Gallic acid, caffeic acid and pyrogallol. Microbial Pathogenesis 99:56-61. doi:10.1016/j.micpath.2016.08.004.

Martínez, G., Regente, M., Jacobi, S., Del Rio, M., Pinedo, M., and de la Canal, L. 2017. Chlorogenic acid is a fungicide active against phytopathogenic fungi. Pesticide Biochemistry and Physiology 140:30-35. doi:10.1016/J.PESTBP.2017.05.012.

Meléndez-González, C., Murià-González, M.J., Anaya, A.L., Hernández-Bautista, B.E., Hernández-Ortega, S., González, M.C., et al. 2015. Acremoxanthone E, a novel member of heterodimeric polyketides with a bicyclo[3.2.2]nonene ring, produced by Acremonium camptosporum W. Gams (Clavicipitaceae) endophytic fungus. Chemistry \& Biodiversity 12(1):133-147. doi:10.1002/cbdv.201300370. 
Michel, T., Destandau, E., Le Floch, G., Lucchesi, M.E., and Elfakir, C. 2012. Antimicrobial, antioxidant and phytochemical investigations of sea buckthorn (Hippophä̈ rhamnoides L.) leaf, stem, root and seed. Food Chemistry 131(3):754-760. doi:10.1016/J.FOODCHEM.2011.09.029.

Oliveira, V.M., Carraro, E., Auler, M.E., and Khalil, N.M. 2016. Quercetin and rutin as potential agents antifungal against Cryptococcus spp. Brazilian Journal of Biology 76:1029-1034.

Pérez-Ochoa, M.L., Chávez-Servia, J.L., Vera-Guzmán, E.N., Aquino-Bolaños, A.M., and Carrillo-Rodríguez, J.C. 2016. Medicinal plants used by indigenous communities of Oaxaca, Mexico, to treat gastrointestinal disorders. p. 1-13. In Perveen, S. (ed.) Pharmacognosy Medicinal Plants. IntechOpen Limited, London, UK.

Pusztahelyi, T., Holb, I.J., and Pócsi, I. 2015. Secondary metabolites in fungus-plant interactions. Frontiers in Plant Science 6:573. doi:10.3389/fpls.2015.00573

Re, R., Pellegrini, N., Proteggente, A., Pannala, A., Yang, M., and Rice-Evans, C.1999. Antioxidant activity applying an improved ABTS radical cation decolorization assay. Free Radical Biology and Medicine 26(9-10):1231-1237. doi:10.1016/S0891-5849(98)00315-3.

Rhouma, A., Ben Daoud, H., Ghanmi, S., Ben Salah, H., Romdhane, M., and Demak, M. 2009. Antimicrobial activities of leaf extracts of pistacia and schinus species against some plant pathogenic fungi and bacteria. Journal of Plant Pathology 91(2):339-345. http://www.jstor.org/stable/41998628.

Rodríguez-Pedroso, A.T., Ramirez-Arrebato, M., Bautista-Baños, S., Cruz-Triana, A., y Rivero, D. 2012. Actividad antifúngica de extractos de Acacia farnesiana sobre el crecimiento in vitro de Fusarium oxysporum f. sp. lycopersici. Revista Científica UDO Agrícola 12(1):91-96.

Seleem, D., Pardi, V., and Murata, R.M. 2017. Review of flavonoids: A diverse group of natural compounds with anti-Candida albicans activity in vitro. Archives of Oral Biology 76:76-83. doi:10.1016/j.archoralbio.2016.08.030.

Smith, A.R., and Zhao, D. 2016. Sterility caused by floral organ degeneration and abiotic stresses in Arabidopsis and cereal grains. Frontiers in Plant Science 7:1503. doi:10.3389/fpls.2016.01503.

Varela, M.C., Arslan, I., Reginato, M.A., Cenzano, A.M., and Luna, M.V. 2016. Phenolic compounds as indicators of drought resistance in shrubs from Patagonian shrublands (Argentina). Plant Physiology and Biochemistry 104:81-91. doi:10.1016/J.PLAPHY.2016.03.014.

Waterman, P.G., and Mole, S. 1994. Analysis of phenolic plant metabolites. Blackwell Scientific, Oxford, UK.

Wianowska, D., Garbaczewska, S., Cieniecka-Roslonkiewicz, A., Dawidowicz, A.L., and Jankowska, A. 2016. Comparison of antifungal activity of extracts from different Juglans regia cultivars and juglone. Microbial Pathogenesis 100:263-267. doi:10.1016/j.micpath.2016.10.009.

Zabka, M., and Pavela, R. 2013. Antifungal efficacy of some natural phenolic compounds against significant pathogenic and toxinogenic filamentous fungi. Chemosphere 93(6):1051-1056. doi:10.1016/j.chemosphere.2013.05.076. 